Katarzyna Kocot-Górecka

Instytut Statystyki i Demografii

Szkoła Główna Handlowa

kkocot@sgh.waw.pl

\title{
KULTUROWE ROLE PŁCI I DZIETNOŚĆ W POLSCE I NORWEGII
}

\section{WPROWADZENIE}

W Polsce jeszcze przed 1989 rokiem zaczął się spadek płodności, która w miastach już od drugiej połowy lat 1960-tych nie gwarantowała prostej zastępowalności pokoleń. W latach 1990-tych tempo obniżania się współczynników dzietności w całym kraju zwiększyło się. W tym samym czasie następowały również inne zmiany w formowaniu i rozwoju rodziny: spadała liczba zawieranych małżeństw mimo tego, że rosła liczba osób w wieku 20-29 lat, związki małżeńskie były zawierane coraz później, wzrastał wiek kobiet rodzących pierwsze dziecko, zwiększała się liczba rozwodów. Te nowe procesy miały miejsce również w innych krajach Europy Środkowo-Wschodniej. Za główne ich przyczyny uważa się niekorzystne zmiany warunków uczestnictwa na rynku pracy, w tym zagrożenia bezrobociem i rosnącej niepewności zatrudnienia, jak również ograniczenie funkcji opiekuńczej państwa (Kotowska 1999, Frejka 2008, Kotowska 2009).

Przemiany polityczno-gospodarcze w 1989 roku zapoczątkowały w Polsce również inne procesy społeczne. Wśród nich istotne miejsce zajmują zmiany postaw wobec kulturowych ról płci. Jednak na początku liberalizacji gospodarki nie towarzyszyła liberalizacja poglądów na temat roli kobiet. W poprzedniej epoce, pomimo propagowania pracy zawodowej kobiet, nie naruszono tradycyjnego podział obowiązków pomiędzy kobietą i mężczyzną (Kałwa i Klich-Kluczewska 2012). Pracę zarobkową kobiet traktowano tylko jako źródło uzupełnienia dochodów gospodarstwa domowego. Jednocześnie utrzymywały się wysokie oczekiwania wobec kobiet odnośnie ich roli w rodzinie. Sprzyjały temu trudności w zaopatrzeniu w produkty niezbędne rodzinie i ułatwiające prace domowe. Pokonywanie ich wymagało wiele czasu i sił (np. stanie w kolejkach, pranie) (Siemieńska 1996). W trakcie dokonujących się zmian na rynku pracy w latach 1990-tych, gdy w krótkim czasie powstało duże bezrobocie i wiele miejsc pracy zostało zlikwidowanych, aż 55\% Polaków 
uważało, że kobiety mają mniejsze prawo do miejsc pracy niż mężczyźni (Siemieńska 2000). Jednak przy dużej niepewności zatrudnienia i rosnących kosztach utrzymania zarobki kobiet zaczęły nabierać ważniejszego znaczenia dla bezpieczeństwa finansowego rodziny. Tym samym rosnąca świadomość wagi pracy zawodowej kobiet i wzrost ich wykształcenia, a także wykształcenia mężczyzn, musiały wpłynąć na zmianę postaw wobec ról kobiet (Siemieńska 2011).

Zmiany postaw wobec kulturowych ról płci w Europie Zachodniej i Północnej, które miały miejsce po II wojnie światowej, współwystępowały z rosnącą aktywnością zawodową kobiet. Zwiększający się udział kobiet w rynku pracy określany jest przez niektórych badaczy jako pierwszy etap rewolucji kulturowych ról płci, który wywarł istotny wpływ na procesy demograficzne (Goldscheider, Bernhardt i Lappegård 2014, 2015, Esping-Andersen 2009, Esping-Andersen i Billari 2015). Jednocześnie coraz wyraźniejszy trend spadkowy płodności sprawił, że dzietność w rosnącej liczbie krajów nie gwarantowała prostej zastępowalności pokoleń, pozostając w znacznej ich części na niskim poziomie (współczynnik dzietności poniżej 1,5), stopniowo wzrastała bezdzietność, coraz większy był udział związków nieformalnych i urodzeń w tych związkach oraz zwiększała się częstość rozwodów. Zgodnie z teorią drugiego przejścia demograficznego za główne przyczyny spadku dzietności w Europie Zachodniej i Północnej, a później i w Europie Południowej, uważa się zmiany w tworzeniu rodzin i ich rozwiązywaniu wynikające ze zmiany norm i postaw (Inglehart 1977, Lesthaeghe i van de Kaa 1986). Wśród nich duże znaczenie przypisuje się wzrostowi egalitaryzmu płci w sferze publicznej (rynek pracy, edukacja) (Goldscheider, Oláh i Puur 2010, Lesthaeghe 2010). Na początku XXI wieku jednak dzietność w krajach skandynawskich, Beneluksu oraz we Francji i Wielkiej Brytanii zaczęła wzrastać, zbliżając się do poziomu gwarantującego prostą zastępowalność pokoleń, natomiast w Europie Południowej i Środkowo-Wschodniej utrzymują się niskie wartości współczynników dzietności.

Spadek płodności w Europie w drugiej połowie XX w. jest też przypisywany nierównowadze pomiędzy wzrostem równości płci $\mathrm{w}$ instytucjach zorientowanych na jednostkę (przede wszystkim rynek pracy i edukacja) a brakiem takich zmian $\mathrm{w}$ instytucjach zorientowanych na rodzinę i w samej rodzinie (McDonald 2000a, 2000b). Powstałe dysproporcje w postrzeganiu roli kobiety w sferze rodzinnej i zawodowej przyczyniały się do podwójnego obciążenia kobiet obowiązkami zawodowymi i domowymi, które z kolei wpływały na ograniczenie urodzeń. Potwierdzeniem tej hipotezy był wzrost płodności w krajach wcześniej wymienionych, w których normy i postawy wobec roli kobiet w rodzinie najwcześniej ewoluowały w kierunku równości w porównaniu do innych rejonów Europy. Zwiększyło się, między innymi, zaangażowanie mężczyzn w obowiązki domowe (Smith 2004). Wprowadzono również sprzyjające rozwiązania polityki społecznej: urlopy dla mężczyzn na opiekę nad małym dzieckiem z finansowym zabezpieczeniem, które zachęcały do ich korzystania oraz elastyczny czas pracy dla kobiet i mężczyzn. Ponadto zapewniono opiekę instytucjonalną dzieciom, również w wieku szkolnym, zgodnie 
z czasem pracy rodziców tak, aby oboje mieli możliwość łączenia pracy zawodowej z opieką nad dzieckiem.

W krajach o różnych uwarunkowaniach historycznych i stosowanych rozwiązaniach polityki społecznej (modele polityki społecznej - welfare regimes) społeczne role płci są postrzegane w niejednakowy sposób. Przejawia się to nie tylko w rozwiązaniach instytucjonalnych, ale i w poglądach kobiet i mężczyzn oraz w praktykowanym podziale obowiązków domowych w rodzinach. Interesującym podejściem do pomiaru warunków łączenia obowiązków rodzinnych i pracy zawodowej jest wskaźnik syntetyczny ICWFR (Index of Conditions for Work and Family Reconciliation) zaproponowany przez Matysiak i Węziak-Białowolską (2013). Składa się on z trzech wskaźników cząstkowych operacjonalizujących trzy obszary: rozwiązania polityki rodzinnej (usługi opiekuńczo-edukacyjne, urlopy), elastyczność rynku pracy i barier wchodzenia na rynek pracy oraz poglądy na temat kulturowych ról płci. Mierniki te wyznaczone dla 25 państw członkowskich Unii Europejskiej i Norwegii wskazały, że kraje skandynawskie oraz Belgia i Francja to kraje europejskie, w których polityka publiczna najlepiej wspiera pracujących rodziców, a zaangażowanie matek na rynku pracy jest społecznie najbardziej akceptowane. W krajach postsocjalistycznych Europy, które nie były wcześniej często uwzględniane w porównywaniach, ujawniło się dość duże zróżnicowanie: w Słowenii dobre warunki do łączenia pracy i opieki, gorsze na Węgrzech, w Estonii, Bułgarii, Łotwie i w Czechach, ale istotnie lepsze niż na Litwie, w Polsce, czy w Rumunii, które znalazły się w dolnej części rankingu. Rezultaty te wykazały pewną zgodność ze stopniem zaangażowania w obowiązki domowe mężczyzn przedstawionym w raporcie Komisji Europejskiej The Role of Men in Gender Equality - European strategies and insights (2012), a mierzonego udziałem ich czasu przeznaczonego na te zajęcia. Stosunkowo najwięcej czasu na obowiązki rodzinne poświęcali mężczyźni w krajach skandynawskich, a najmniej w niektórych krajach Europy Południowej (Grecja, Cypr i Malta) i w kilku krajach postkomunistycznych (Bułgaria, Rumunia, Słowacja i Polska). Jednak Estonia, Łotwa i Słowenia znalazły się wśród krajów o najwyższych udziałach czasu przeznaczanego przez mężczyzn na obowiązki rodzinne. W obu przytoczonych powyżej rankingach Norwegia zajmowała wysokie miejsce, a Polska była wśród państw o najniższych pozycjach na liście rankingowej.

Pozytywny wpływ egalitarnych norm kulturowych ról płci na formowanie rodziny pokazały badania z ostatnich lat. Gimenez-Nadal, Molina i Sevilla-Sanz (2012) i Sevilla-Sanz (2010) wskazali na ich dodatni wpływ na prawdopodobieństwo formowania związku, a Puur i inni (2008) potwierdzili pozytywny związek pomiędzy równowagą w podziale obowiązków domowych i opiekuńczych względem dziecka pomiędzy partnerami a intencją posiadania dziecka wśród mężczyzn. Jednak wśród kobiet takie relacje okazały się bardziej zróżnicowane. Niejednoznaczność kierunków zależności ujawniły analizy Lappegård, Neyer i Vignoli (2015), w których oddzielnie szacowano wpływ na intencje posiadania dziecka egalitarnych postaw 
w sferze publicznej oraz egalitarnych poglądów na role matki i na role ojca w rodzinie. W niektórych krajach (Austria, Norwegia, Węgry i Francja) wśród kobiet ten drugi związek okazał się ujemny.

Wyniki World Values Survey pokazały, że w Europie Zachodniej i Północnej stopień egalitaryzmu w poglądach na role kobiet jest znacznie wyższy niż w Europie Środkowo-Wschodniej (Arpino, Esping-Andersen i Pessin 2015). Ponadto w krajach Europy Północnej, w których podział obowiązków związanych z opieką nad dzieckiem i prowadzeniem prac domowych jest bardziej równomiernie rozłożony między partnerów (kobiety są mniej obciążone tymi obowiązkami), występuje również wysoka, jak na warunki europejskie, dzietność. Może to wskazywać, że zmniejszanie konfliktu pomiędzy obciążeniami w pracy zawodowej i obowiązkami domowymi, szczególnie poprzez zwiększanie równowagi między postawami deklaratywnymi a realizowanymi, sprzyja wyższej dzietności. Pojawienie się takiej równowagi i towarzyszący jej wzrost płodność Goldscheider, Bernhardt i Lappegård $(2014,2015)$ nazwały drugim etapem rewolucji kulturowych ról płci.

Także inni badacze mówią o etapach procesu przemian kulturowych ról płci. Opublikowany przez Arpino, Esping-Andersen i Pessin (2015) schemat zmian płodności względem stopnia zaawansowania przemian kulturowych ról płci wskazuje, że Polska jest w początkowym etapie tego procesu. Etap ten charakteryzuje się spadkiem płodności. Natomiast kraje skandynawskie i Holandia są już w końcowym etapie zmian kulturowych w rolach płci, w którym płodność rośnie.

Rola zaawansowania procesu przemian kulturowych ról płci w wyjaśnianiu zmian płodności w krajach europejskich, czy szerzej w krajach rozwiniętych, podkreślana coraz mocniej w literaturze przedmiotu, były przesłanką do analizy podjętej w niniejszym artykule. Jej celem jest ocena dystansu w postrzeganiu kulturowych ról płci w Polsce w porównaniu do kraju, który jest w grupie liderów procesu przemian kulturowych ról płci, czyli kraju o najwyższym stopniu egalitaryzmu płci oraz ukazanie powiązań między dzietnością a postawami wobec kulturowych ról płci. Skorzystano w niej z danych badania ankietowego Generations and Gender Survey. Jedynym krajem skandynawskim, dla którego została udostępniona baza danych z pierwszej rundy tego badania, gdy podejmowano te analizy, była Norwegia. Pierwszą rundę badania przeprowadzono tam w 2007 roku, zaś w Polsce to badanie było zrealizowane na przełomie 2010 i 2011 roku.

Analizę rozpoczyna opis równości płci w Polsce i Norwegii w ujęciu makro, który zawiera syntetyczne międzynarodowe wskaźniki równości płci oraz charakterystykę przebiegu zmian wykształcenia kobiet, ich aktywności zawodowej i dzietności w ostatnich dwóch dekadach. Następnie porównano postawy wobec kulturowych ról płci z podziałem na deklaratywne i realizowane w rodzinie, ukazując dystans jaki dzieli Polskę i Norwegię. W kolejnym kroku przeprowadzono analizę ich powiązań z dzietnością. Dodatkowo uwzględniono aktywność zawodową, liczbę dzieci w rodzinach oraz intencje prokreacyjne. Analizę uzupełniono również oceną stopnia satysfakcji z obciążenia obowiązkami domowymi według poglądów na role płci. 


\section{RÓWNOŚĆ PŁCI W POLSCE I W NORWEGII - POMIAR I KONTEKST}

W połowie lat 1990-tych zaczęto publikować pierwsze wskaźniki pomiaru równości płci dla różnych krajów. Od tamtego czasu powstało już około trzystu różnych formuł (Hawken i Munck 2012). Obecnie najczęściej są komentowane indeksy przytoczone poniżej. Porównują one głównie efekty rozwiązań instytucjonalnych na rynku pracy, w edukacji, w strukturach rządowych i gospodarczych a niektóre również zdrowie. Skupienie się w nich na informacjach o edukacyjnych i ekonomicznych sferach życia wynika z tego, że niezależność ekonomiczna, a tym samym możliwość utworzenia i utrzymania własnego gospodarstwa domowego i rodziny, uznana jest za jedną z najbardziej istotnych cech równości płci (Orloff 1993, Hobson 1990).

W międzynarodowych zestawieniach indeksów monitorujących równość płci Polska jest usytuowana wiele miejsc za Norwegią, która znajduje się w czołówce. W 2014 roku według rankingu Global Gender Gap Index ${ }^{1}$ Norwegia była na 3 miejscu (w 2013 roku również 3), Polska na 57 (2013 rok - 54 miejsce). Natomiast w rankingu Gender Inequality Index ${ }^{2}$ i Gender Development Index ${ }^{3}$ Norwegia w 2013 roku była odpowiednio na miejscu 9 i 5, a Polska - 26 i 14. Wśród 27 krajów Unii Europejskiej według Gender Equity Index ${ }^{4}$ Polska znalazła się na 17 miejscu. O odległej pozycji Polski zdecydowały przede wszystkim wskaźniki dotyczące sfery ekonomicznej i środowiska politycznego.

Odnośnie edukacji w Polsce w ciągu dwudziestu lat istotnie podniósł się udział kobiet uczących się na wyższych uczelniach. Porównując Polskę i Norwegię w obu

${ }^{1}$ Indeks Global Gender Gap jest wyznaczany przez World Economic Forum i publikowany co roku od 2006 w The Global Gender Gap Report. Ocenia on nierówności płci w ponad 100 krajach świata (w 2014 roku 142 krajach w czterech dziedzinach: ekonomia (wysokość zarobków, udział i dostęp do stanowisk wymagających wysokich kwalifikacji), edukacja (uczęszczanie do szkół na wszystkich poziomach), polityka (udział kobiet w strukturach rządowych) oraz zdrowie (przeciętne dalsze trwanie życia).

${ }^{2}$ Gender Inequality Index mierzy nierówności płci w trzech dziedzinach życia: zdrowie reprodukcyjne (współczynnik umieralności matek i wskaźniki urodzeń wśród nastolatek), życie społeczne (udział miejsc w parlamencie zajmowanych przez kobiety i odsetek dorosłych kobiet i mężczyzn w wieku 25 lat i starszych z co najmniej wykształceniem średnim) oraz status ekonomiczny (współczynniki aktywności ekonomicznej kobiet i mężczyzn w wieku 15 lat i starszych). Wartości indeksów oraz ranking krajów publikowane są w Human Development Report, United Nations Development Programme.

3 Gender Development Index mierzy nierówności płci w trzech podstawowych wymiarach rozwoju człowieka: w zdrowiu (przeciętna dalsza długość życia e ), w edukacji (oczekiwana liczba lat nauki dla dzieci i średnia liczba lat nauki kobiet i mężczyzn w wieku 25 i starszych) oraz status ekonomiczny (porównuje szacowane dochody mężczyzn i kobiet). Wartości indeksów oraz rankingi krajów publikowane są w Human Development Report, United Nations Development Programme.

${ }^{4}$ Gender Equity Index używany przez Social Watch od 2007 roku, mierzy poziom równouprawnienia $w$ trzech dziedzinach życia. Bierze pod uwagę udział płci w edukacji (poziom analfabetyzmu, odsetek osób z podstawowym, średnim i wyższym wykształceniem), status ekonomiczny (poziom płac i zatrudnienia), w życiu publicznym (odsetek kobiet na stanowiskach kierowniczych, podstawowych, w parlamencie i rządzie). 
krajach udział kobiet z wykształceniem wyższym w wieku 25-34 wzrósł w ciągu ostatnich dwóch dekad, ale tempo zmian było znacznie szybsze w Polsce. W 1997 roku w Polsce udział procentowy kobiet z wyższym wykształceniem był prawie dwa razy niższy niż w Norwegii. Po 18 latach w 2014 roku w Norwegii wynosił 58,7\%, a w Polsce już niewiele mniej bo $51,7 \%{ }^{5}$.

W Polsce pod koniec lat 1980-tych współczynniki aktywności zawodowej kobiet w wieku 15-64 lata były na poziomie około 64\%. Po 1989 roku aktywność zawodowa się obniżyła. Trend spadkowy aktywności zawodowej kobiet, jaki pojawił się w okresie transformacji utrzymywał się do 2007 roku, a wzrost obserwowany w następnych latach (do 61,1\% w 2014 roku) nie doprowadził jeszcze do osiągnięcia poziomu aktywności sprzed transformacji społeczno-gospodarczej (Rysunek 1). Główną przyczyną spadku udziału kobiet w rynku pracy była zmiana gospodarki centralnie planowanej na rynkową. Pojawiło się duże bezrobocie, wzrosły znacząco wymagania rynku pracy. Kobiety doświadczały większego ryzyka pozostawania bez pracy, w tym także ryzyka bezrobocia długookresowego. Długotrwałe bezrobocie kobiet, wynikające w dużym stopniu z postrzegania ich przez pracodawców jako bardziej kłopotliwych i mniej dyspozycyjnych pracowników, spowodowało wycofywanie się kobiet z rynku pracy (Kotowska 1999). Jednak porównania współczynników aktywności kobiet w wieku 25-49 lat pokazują, że prawie się one nie zmieniły.

Norwegię charakteryzował wzrost aktywności zawodowej kobiet, a następnie jej stabilizacja na poziomie bliskim 75\%. Generalnie od 1972 do 2013 roku współ-

Rysunek 1. Współczynniki aktywności ekonomicznej kobiet w wieku 15-64 lata i 25-39 lat w Polsce i w Norwegii, 1992-2014

Figure 1. Economic activity rates of women at the aged 15-64 years and 25-39 years in Poland and Norway, 1992-2014

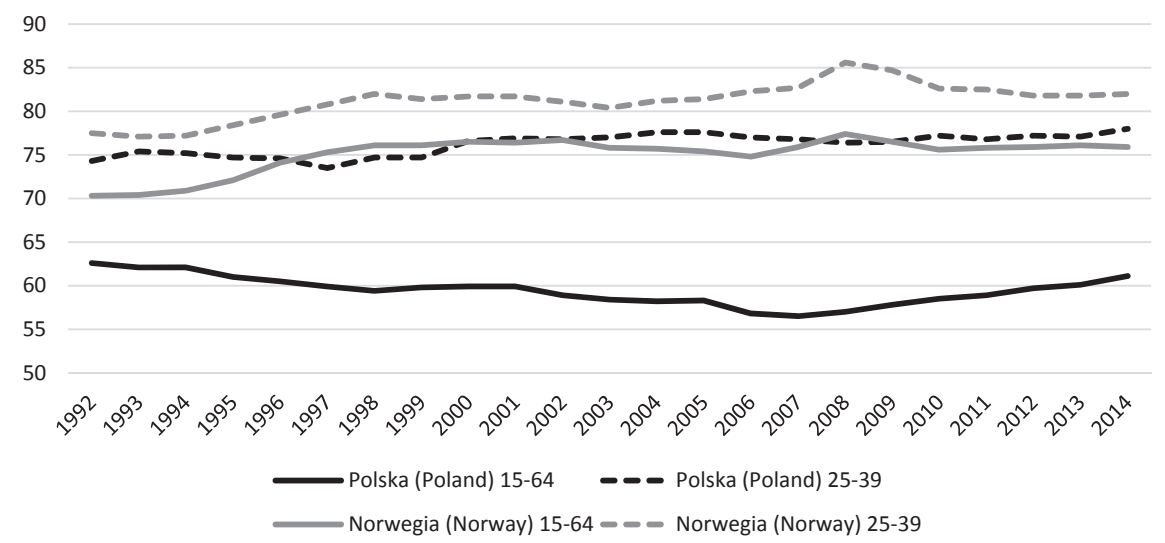

Źródło: dane OECD.

Source: OECD database.

${ }^{5}$ Dane Eurostatu bazujące na EU-LFS tabela: Population with tertiary education attainment by sex and age. 
czynnik aktywności zawodowej kobiet w wieku 15-64 lata wzrósł z 49,1\% do 76\%, a w roku 1989 miał wartość już 70,9\% czyli o prawie 7 punktów procentowych więcej niż w tym czasie w Polsce.

Interesująco również przedstawia się zestawienie współczynników aktywności zawodowej kobiet w wieku 25-39 lat, które są wyraźnie wyższe od współczynników ogólnych. Przebieg zmian aktywności tej grupy kobiet w Norwegii był podobny do zmian ogólnego współczynnika aktywności, tylko dotyczył wyższych wartości - od 77,5\% w 1972 roku do 85,6\% w 2008 roku i 82\% w 2014 roku. W Polsce spadek aktywności kobiet w tym wieku wystąpił do 1997 roku, później miał miejsce stopniowy wzrost lub stabilizacja wokół poziomu obserwowanego dla współczynnika ogólnego w Norwegii. Najmniejsze różnice między aktywnością kobiet $\mathrm{w}$ tej grupie wieku, newralgicznej dla decyzji prokreacyjnych, w obu krajach były w latach 1993-1994 (1,6-2 punkty procentowe) a największe w latach 1997-1999 i 2008-2009 (od 6,8-9,3 punktów procentowych). Obecnie różnica ta zmniejszyła się do 4 punktów procentowych ${ }^{6}$ (Rysunek 1).

Przytoczone powyżej informacje o edukacji i aktywności zawodowej ilustrują zmiany zachowań kobiet $\mathrm{w}$ sferze społecznej i ekonomicznej. W Norwegii zmiany te rozpoczęły się znacznie wcześniej i współwystępowały ze stopniowo rosnącą społeczną akceptacją pracujących zawodowo kobiet, a zwłaszcza pracujących matek. Sprzyjała temu polityka społeczna, która tworzyła rozwiązania skierowane zarówno do kobiet jak i mężczyzn ułatwiające łączenie obowiązków rodzinnych i zawodowych. Jednym $z$ takich ważnych elementów było zatrudnienie w niepełnym wymiarze czasu (Rysunek 2). W Norwegii z takich rozwiązań korzystały przede wszystkim kobiety, ale procent mężczyzn pracujących w niepełnym wymiarze na tle wielu europejskich krajów stał się również wysoki. Korzystanie z takiej formy zatrudnienia

Rysunek 2. Udział kobiet i mężczyzn zatrudnionych w niepełnym wymiarze godzin wśród zatrudnionych w Polsce i Norwegii, 2000-2013 (w\%)

Figure 2. Proportion of women and men engaged in part-time employment among employed in Poland and Norway, 2000-2013 (\%)

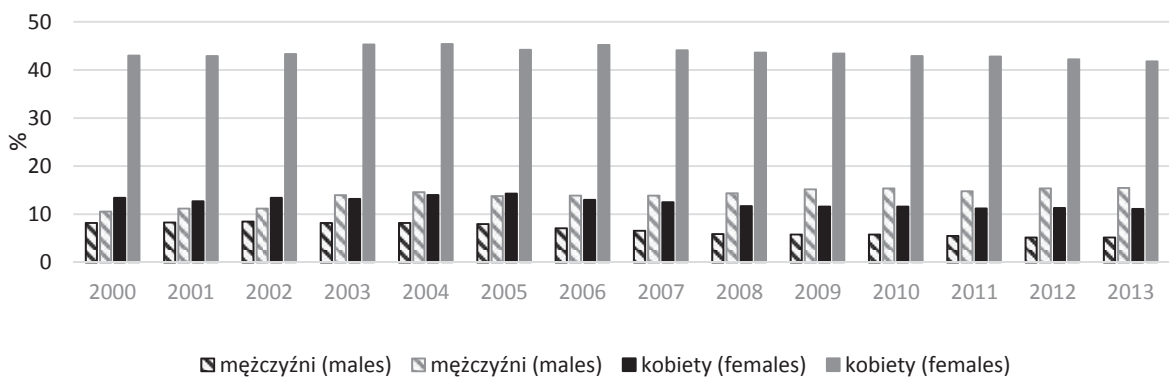

Źródło: dane Eurostat.

Source: Eurostat database.

${ }^{6}$ Dane OECD tabela: LFS by sex and age - indicators. 
ma istotny wpływ na wskaźniki zatrudnienia szczególnie wśród kobiet posiadających małe dzieci. W Polsce stopień wykorzystania zatrudnienia $\mathrm{w}$ niepełnym wymiarze jest znacznie mniejszy. Różnice wskaźników zatrudnienia w młodszych grupach wieku w Polsce i Norwegii potwierdzają ich znaczenie dla kształtowania się stopnia zaangażowania kobiet na rynku pracy (Rysunek 3).

Rysunek 3. Wskaźniki zatrudnienia kobiet według wieku w Polsce i w Norwegii w latach 1992-2014

Figure 3. Labour force participation rates of women by the age in Poland and Norway, 1992-2014

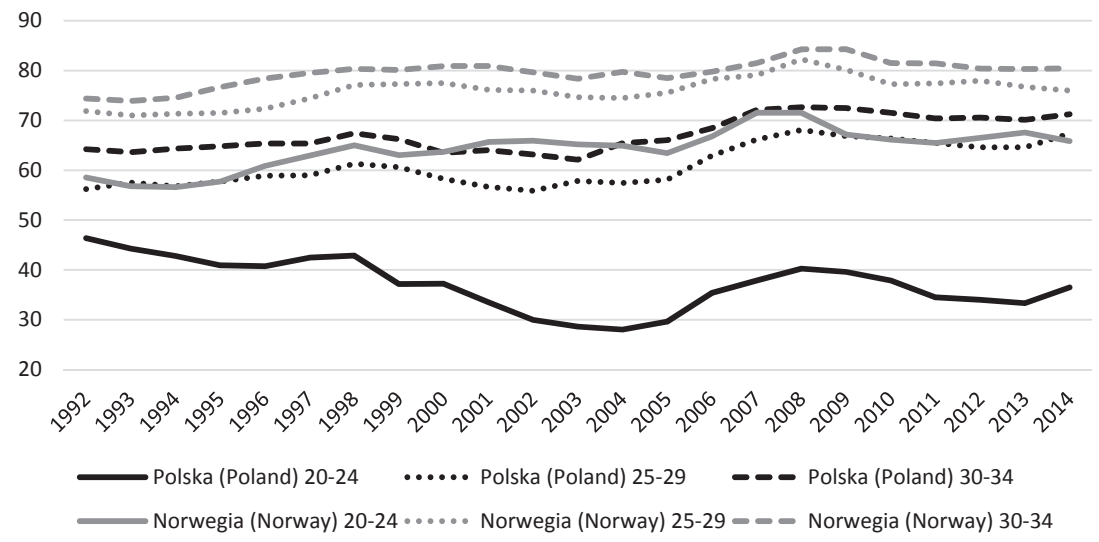

Źródło: dane OECD.

Source: OECD database.

Opisanym powyżej trendom aktywności zawodowej i edukacji towarzyszyły zmiany płodności. Kiedy w Polsce w 1984 roku przekrojowy współczynnik dzietności był na poziomie 2,4, w Norwegii osiągnął najniższą wartość 1,66. Od tego roku przekrojowe współczynniki dzietności w tym kraju zaczęły ponownie wzrastać, zaś w Polsce nastąpił powrót do trendu malejącego, który trwał do 2003 roku (współczynnik dzietności osiągnął wartość 1,22). W następnych latach kierunek zmian współczynników dzietności był podobny jak w Norwegii, ale wartości były istotnie niższe: w Polsce od 1,22 w 2003 roku do 1,40 w 2009 roku a w Norwegii od 1,83 do 1,98. Od 2010 roku w obu krajach obserwowany jest spadek płodności (Rysunek 4).

W tym samym czasie w obu krajach systematycznie i w zbliżonym tempie wzrastał średni wiek macierzyństwa, choć w Polsce zauważalne opóźnianie prokreacji wystąpiło dopiero po 1989 roku. W 2013 roku średni wiek urodzenia dziecka w Norwegii osiągnął 30,5 roku, a w Polsce - 29 lat. Nieznacznie szybciej rósł średni wiek urodzenia pierwszego dziecka, ale mimo silniejszych zmian w Polsce w ostatnich dwóch dekadach różnica pozostała: w Norwegii w 2013 roku wynosił 28,6 roku, w Polsce - 26,7 roku ${ }^{7}$.

${ }^{7}$ Dane Eurostatu tabela: Fertility indicators. 
Rysunek 4. Przekrojowe współczynniki dzietności w Polsce i w Norwegii w latach 1980-2013

Figure 4. Total fertility rates in Poland and Norway, 1980-2013

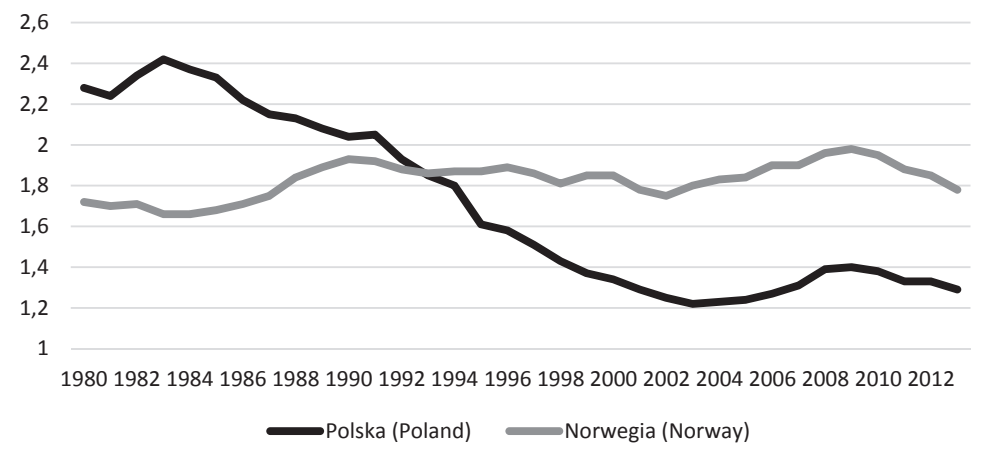

Źródło: dane Eurostat.

Source: Eurostat database.

Zestawienie przebiegu zmian aktywności zawodowej kobiet i dzietności w ostatnich dwóch dekadach pokazuje, iż kierunki zależności pomiędzy tymi dwoma procesami w Norwegii i w Polsce są odmienne (zob. Del Boca i in. 2003). Szczególnie widoczne jest to w grupie wieku 25-39 lat, w której ujawniało się wyższe zaangażowanie kobiet na rynku pracy w obu krajach niż w młodszych grupach. W Norwegii współczynnik korelacji Pearsona wyznaczony dla współczynników aktywności zawodowej i współczynników dzietności w latach 1992-2013 w tej grupie wieku wyniósł 0,8 , co ilustruje wyraźną dodatnią zależność pomiędzy aktywnością zawodową kobiet i płodnością. Dla Polski współczynnik korelacji przyjął wartość bliską zeru $(-0,09)$, co wskazuje na jej brak (Rysunek 5). Takie wyniki potwierdzają istnienie w Norwegii warunków sprzyjających łączeniu pracy zawodowej i obowiązków rodzinnych, które pozwalają na utrzymywanie wysokiej aktywności zawodowej kobiet i wyższej płodności młodych kobiet, a w Polsce - brak takich warunków. Znacznie niższa aktywności niż w Norwegii kobiet w wieku 25-39 lat współwystępuje z bardzo niską płodnością.

Przedstawione powyżej wyniki dotyczące współwystępowania współczynników dzietności i aktywności zawodowej kobiet wpisują się w ustalenia Matysiak (2011). Jej praca, dotycząca przekrojowej analizy korelacji miedzy współczynnikami dzietności i aktywności zawodowej kobiet objęła nie tylko kraje Europy Zachodniej i Północnej, już wcześniej analizowane w stosunkowo licznych pracach (Ahn i Mira 2002, Engelhardt i Prskawetz 2004, Kögel 2004, D’Addio i D’Ercole 2005), ale również kraje Europy Środkowo-Wschodniej, które wcześniej nie były ujmowane w tych analizach. Pogłębione analizy pokazały, że zmiana korelacji negatywnej na pozytywną na poziomie makro nastąpiła w pierwszej grupie krajów już w połowie lat 1980-tych, a w drugiej grupie krajów, czyli Europy Środkowo-Wschodniej około 2005 roku. 
Rysunek 5. Przekrojowe współczynniki dzietności (TFR) i współczynniki aktywności zawodowej (LFP) kobiet w wieku 25-39 lat w Polsce i w Norwegii, 1992-2013

Figure 5. Total fertility rate (TFR) and labour force participation rates (LFP) of women aged 25-39 in Poland and Norway, 1992 to 2013

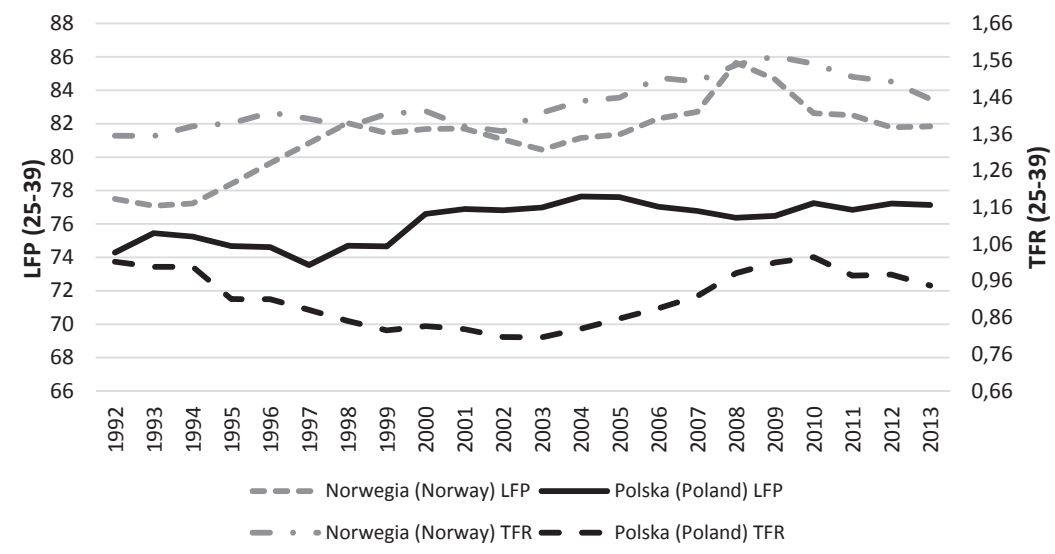

Źródło: obliczenia własne na podstawie danych Eurostat i OECD.

Source: own calculations based on Eurostat and OECD database.

Dotychczasowe rozważania dotyczyły współzależności współczynników aktywności zawodowej i współczynników dzietności w Polsce i Norwegii, generowanych przez zachowania kobiet na rynku pracy i zachowania prokreacyjne. W następnej części artykułu skupimy się na opisowej analizie postaw kobiet i mężczyzn wobec kulturowych ról płci, stanowiącej etap wstępny do przyszłych pogłębionych studiów nad postawami deklaratywnymi i realizowanymi w rodzinie oraz ich powiązaniach z płodnością mężczyzn i kobiet.

\section{DANE I METODA}

Cechy jednostkowe, które mogą wpływać na poglądy deklarowane wobec kulturowych ról płci kobiet i mężczyzn oraz na podział obowiązków w rodzinie, zostały określone na podstawie danych z badania Generations and Gender Survey (GGS-1) zrealizowanego w Norwegii w 2007 r. na reprezentatywnej próbie około 15 tys. osób oraz w Polsce na przełomie 2010 i 2011 r. na reprezentatywnej próbie około 20 tys. osób. Respondentom zadano pytania dotyczące opinii na temat równości płci w sferze publicznej, w związku pomiędzy współmałżonkami/partnerami i odpowiedzialności wobec dzieci oraz o podział zobowiązań w rodzinie. Badanie nie zawierało informacji o czasie poświęconym na wykonywanie tych obowiązków. Na podstawie odpowiedzi na odpowiedni zestaw pytań skonstruowano dwie zmienne (wskaźniki) syntetyczne opisujące wygłaszane poglądy odnośnie kulturowych ról płci oraz subiektywną ocenę obciążenia obowiązkami domowymi i wynikającymi z posiadania małych dzieci. Aby 
umożliwić porównanie obu wskaźników wyznaczono je dla osób w wieku 20-44 lata mieszkających ze współmałżonkiem/partnerem.

Zasady konstrukcji syntetycznego wskaźnika opisującego poglądy dotyczące kulturowych ról płci są zamieszczone w poniższej tabeli. Do jego utworzenia wykorzystano dziesięć pytań dotyczących poglądów i zsumowano odpowiedzi według skali Likerta. W ten sposób utworzono wskaźnik wyrażający stopień aprobaty równości płci (egalitaryzmu) w obu krajach (Tabela 1).

Tabela 1. Konstrukcja zmiennej 'poglądy'

Table 1. Construction of the 'opinions' variable

Poglądy o równości płci - wskaźnik 'poglądy'

Opinions on gender equality - 'opinions' variable

Suma kodów stopnia poparcia dziesięciu poniższych opinii:

- Ogólnie rzecz biorąc mężczyźni są lepszymi przywódcami politycznymi niż kobiety.

- W sytuacji, kiedy brakuje miejsc pracy, mężczyźni powinni mieć większe prawo do pracy niż kobiety.

- Lepiej jest, aby w związku mężczyzna był starszy od kobiety.

- Nie jest dobrze dla związku, jeśli kobieta zarabia więcej niż mężczyzna.

- Gdy rodzice są w potrzebie, córki powinny zajmować się nimi więcej niż synowie

- Jest ze szkodą dla małego dziecka, gdy jego matka pracuje

- Jest ze szkodą dla dzieci, gdy ich ojcowie zbytnio koncentrują się na pracy zawodowej

- Jeśli rodzice rozwiodą się, lepiej jest dla dziecka, aby zostało z matką niż z ojcem

- Kobieta musi mieć dzieci, by czuć się spełniona

- Kobieta nie może zdecydować się na dziecko, jeśli nie chce pozostawać w stałym związku $\mathrm{z}$ mężczyzną

Respondenci wybierali dla każdej opinii jedną z odpowiedzi ze skali Likerta, którym zostały W następujący sposób przypisane kody: zdecydowanie zgadzam się $=1$; zgadzam się $=2$; ani się zgadzam ani się nie zgadzam $=3$; nie zgadzam się $=4$; zdecydowanie nie zgadzam się $=5$. Im wyższa wartość sumy, tym postawa jest bardziej egalitarna.

Zakres zmienności wskaźników wyznaczonych dla Polski i Norwegii jest taki sam: przyjmują wartości od 10 do 50. Do analizy wybrano osoby, które udzieliły odpowiedzi na wszystkie pytania.

Wskaźnik „obciążenie obowiązkami” utworzyły odpowiedzi na 10 pytań odnoszących się do prac domowych i opiekuńczych wobec małego dziecka. Miara ta nie ocenia równości podziału pomiędzy partnerami. Wartości jej wskazują tylko na stopień obciążenia kobiet lub mężczyzn tymi obowiązkami (Tabela 2).

Kolejnym krokiem było pogrupowanie uzyskanych wartości wskaźników na trzy kategorie. Każdy rozkład wartości wskaźników został podzielony na trzy przedziały według odchyleń standardowych odpowiednich dla danego kraju: wartości niskie, typowe i wysokie. Dla wskaźników „poglądy” przedziały zostały odpowiednio nazwane: tradycyjne, umiarkowane i nowoczesne. W przypadku wskaźników „obciążenie obowiązkami” przedziały nazwano odpowiednio: małe, średnie, duże. Ze względu na duże rozbieżności w rozkładach „poglądów” dla Polski i Norwegii poszczególne przedziały utworzone według odchyleń standardowych o tych samych nazwach nie są identycznymi przedziałami w wartościach bezwzględnych. Poglądy „tradycyjne” w Norwegii to w dużym stopniu poglądy „umiarkowane” w Polsce. 
Tabela 2. Konstrukcja zmiennej 'obciążenie obowiązkami'

Table 2. Construction of the 'burden of responsibilities' variable

\section{Obciążenie obowiązkami domowymi i opiekuńczymi wobec małego dziecka - wskaźnik 'obciążenie obowiązkami' \\ Household responsibilities including child care - 'housework and childcare' variable}

Suma kodów stopnia udziału respondenta w wykonywaniu poniższych czynności. Aby zachować porównywalność wybrano dziesięć czynności na temat, których wypowiadali się respondenci w obu krajach i które mogą dotyczyć wszystkich rodzin z dziećmi w wieku do 14 lat.

- Ubieranie dzieci lub doglądanie, aby były odpowiednio ubrane

- Usypianie dzieci i/lub doglądanie, aby poszły do łóżka

- Przebywanie z dziećmi w domu, gdy są chore

- Zabawa z dziećmi i/lub spędzanie z nimi czasu wolnego

- Odprowadzanie dzieci do i ze szkoły, przedszkola, opiekunki, czy zajęć pozalekcyjnych

- Przygotowanie codziennych posiłków

- Zmywanie naczyń

- Kupowanie żywności

- Sprzątanie mieszkania

- Małe naprawy w domu i wokół domu

Respondenci wybierali dla każdej opinii jedną z odpowiedzi ze skali udziału respondenta w obowiązkach, którym zostały w następujący sposób przypisane kody: zawsze partner lub ktoś inny $=1$; najczęściej partner $=2$; po równo respondent $\mathrm{z}$ partnerem $=3$; najczęściej respondent $=4$; zawsze respondent $=5$. Im wyższa wartość sumy, tym większe obciążenie respondenta obowiązkami. Zakres zmienności wskaźników wyznaczonych dla Polski i Norwegii jest taki sam. Ponieważ nad bardzo małymi dziećmi opieka często jest sprawowana w domu czynność odprowadzanie dzieci ich nie dotyczy i dlatego zmienność sum kodów była od 9 do 50 .

Dlatego dodatkowo, aby porównać respondentów o takich samych wartościach wskaźników w obu krajach wprowadzono również podział respondentów z Norwegii według skali wyznaczonej dla Polski.

Utworzone kategorie wskaźników postaw deklarowanych i realizowanych wykorzystane zostały do oceny ich współwystępowania z poczuciem satysfakcji z obciążenia obowiązkami i intencji prokreacyjnych. Miernik satysfakcji został skonstruowany jako suma dwóch ocen satysfakcji: z podziału obowiązków opiekuńczych wobec małych dzieci i z podziału innych obowiązków domowych. Jego wartość zawierała się w przedziale od 0 do 20.

Do oceny różnic pomiędzy średnimi wartościami zmiennych zastosowano testy istotności, przyjmując poziom istotności $\mathrm{p}=0,05$.

\section{ANALIZA OPISOWA POSTAW DEKLARATYWNYCH I REALIZOWANYCH WOBEC KULTUROWYCH RÓL PŁCI W POLSCE I W NORWEGII}

Ankieta pierwszej rundy panelowego badania Generations and Gender Survey (GGS-1) była skierowana do osób w wieku od 18 do 79 lat. W poniższej analizie grupa respondentów została ograniczona do osób w wieku 20-44 lata (czyli wieku w którym prawie wszystkie decyzje prokreacyjne dotyczące urodzenia pierwszego 
i drugiego dziecka są realizowane), posiadających dzieci w wieku do 14 lat i mieszkających z partnerem lub współmałżonkiem. Wybór takiej grupy umożliwił porównanie w obu krajach zarówno poglądów jak i obciążenia obowiązkami domowymi i opiekuńczymi wobec małego dziecka.

Rozkłady poglądów i obciążeń obowiązkami pokazują wyraźne różnice pomiędzy krajami. Dla respondentów z Polski rozkłady były zbliżone do rozkładu normalnego i wykazywały duże podobieństwo dla obu płci tylko z niewielką przewagą wśród kobiet poglądów bardziej nowoczesnych (Rysunek 6). Podobieństwo rozkładów kobiet i mężczyzn potwierdziły również średnie, przyjmujące wartości bardzo zbliżone i ze środka skali. W Norwegii poglądy na temat kulturowych ról płci były bardziej egalitarne, co ilustrują rozkłady wyraźnie przesunięte do wyższych wartości wskaźników „poglądy”. Widać większe różnice pomiędzy kobietami i mężczyznami, mającymi częściej mniej nowoczesne poglądy niż kobiety. Wskazują na to również średnie, ale ich wartości były znacznie wyższe niż wśród respondentów w Polsce (Tabela 3).

Również rozkłady obciążeń obowiązkami pokazały wyraźne różnice pomiędzy Polską i Norwegią (Rysunek 7). W Polsce bardzo wyraźnie widać dużą rozbieżność

Rysunek 6. Rozkłady zmiennej 'poglądy na temat równości płci' według płci w Polsce i w Norwegii Figure 6. Distribution of the variable 'opinions' by sex in Poland and Norway
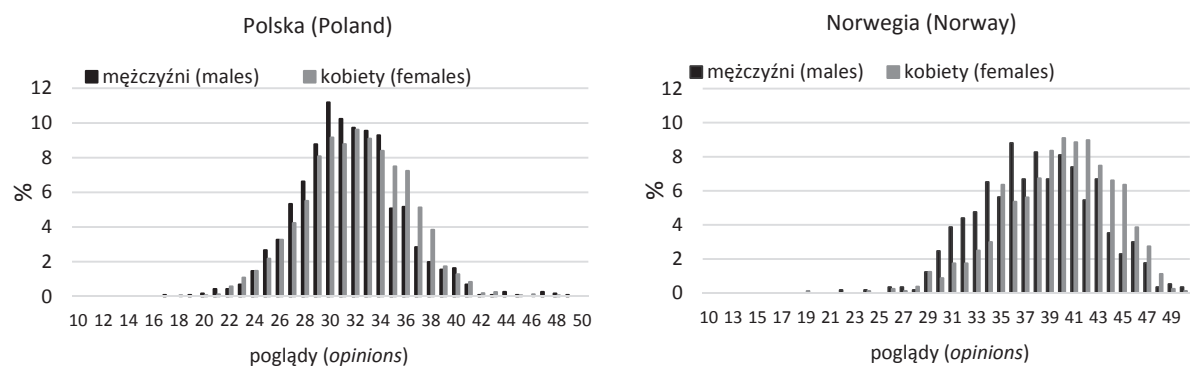

Źródło: obliczenia własne.

Source: own calculations.

Tabela 3. Średnie wartości zmiennych 'poglądy’ i ‘obciążenie obowiązkami’ według płci w Polsce i w Norwegii

Table 3. Mean values of the variables 'opinions' and 'housework and childcare' by sex in Poland and Norway

\begin{tabular}{|l|c|c|c|c|}
\hline \multirow{2}{*}{ Kraj (country) } & \multicolumn{2}{|c|}{ Poglądy (opinions) } & \multicolumn{2}{c|}{$\begin{array}{c}\text { Obciążenia obowiązkami } \\
\text { (housework and childcare) }\end{array}$} \\
\cline { 2 - 5 } & Mężczyźni (male) & Kobiety (female) & Mężczyźni (male) & Kobiety (female) \\
\hline Polska (Poland) & 31,53 & 31,93 & 24,13 & 33,91 \\
\hline Norwegia (Norway) & 38,09 & 39,73 & 27,45 & 30,54 \\
\hline
\end{tabular}

Źródło: obliczenia własne.

Source: own calculations. 
na niekorzyść kobiet. Były one nie tylko znacznie częściej bardziej obciążone od mężczyzn w Polsce, ale również od kobiet w Norwegii, a mężczyźni w Polsce byli najmniej obciążeni, również w porównaniu do mężczyzn w Norwegii. Obciążenia respondentów w Norwegii były bardziej skupione wokół środkowych wartości na skali, a różnice pomiędzy kobietami i mężczyznami wydają się w porównaniu do Polski bardzo małe. Wskazuje to na częstsze wykonywanie połowy obowiązków domowych przez kobiety i mężczyzn w Norwegii.

Rysunek 7. Rozkłady zmiennej 'obciążenie obowiązkami' według płci w Polsce i w Norwegii

Figure 7. Distribution of the variable 'housework and childcare' by sex in Poland and Norway
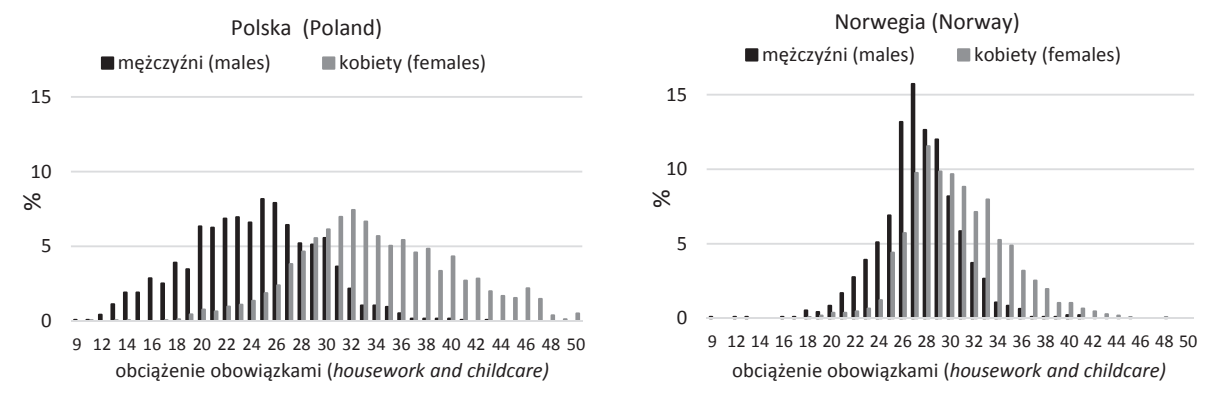

Źródło: obliczenia własne.

Source: own calculations.

Istotną różnicę pomiędzy Polską i Norwegią ujawniło zestawienie średnich wartości wskaźników „poglądy” i „obciążenie obowiązkami” według liczby posiadanych dzieci. $\mathrm{W}$ obu krajach poglądy bardziej nowoczesne miały osoby nie posiadające dzieci, a najbardziej tradycyjne - osoby z czwórką dzieci. Jednak Norwegowie niezależnie od płci i liczby posiadanych dzieci wypowiadali bardziej nowoczesne poglądy oraz wśród nich były mniejsze różnice pomiędzy rodzicami jednego lub dwójki dzieci (a nawet trójki) a osobami nie posiadającymi dzieci. Większe zróżnicowanie tych poglądów według liczby dzieci wystąpiło w Polsce (Rysunek 8).

Inaczej przedstawiają się rozkłady obciążeń obowiązkami domowymi i opiekuńczymi wśród rodziców jednego, dwojga lub trojga dzieci w wieku do 14 lat. Różnice między kobietami i mężczyznami w Polsce w porównaniu do respondentów z Norwegii były wyraźniejsze (Rysunek 9). W Polsce kobiety w większym stopniu wykonywały prace domowe w porównaniu do kobiet w Norwegii, a mężczyźni w znacznie mniejszym stopniu uczestniczyli w tych pracach. Również wzrost liczby dzieci nie zmieniał istotnie średniego udziału mężczyzn w Polsce w pracach domowych i opiekuńczych, zaś wpływał na udział ojców w pracach domowych w Norwegii. Dla kobiet zarówno w Polsce jak i w Norwegii obciążenie przy większej liczbie dzieci istotnie wzrastało ${ }^{8}$.

${ }^{8}$ Odrzucenie hipotez o braku istotnych różnic pomiędzy średnimi wielkościami zmiennych ,poglą-

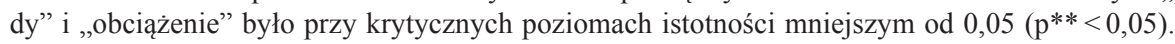


Rysunek 8. Średnie poziomy zmiennej 'poglądy' według płci i liczby dzieci w Polsce i Norwegii

Figure 8. Mean values of the variable 'opinions' by sex and number of children in Poland and Norway

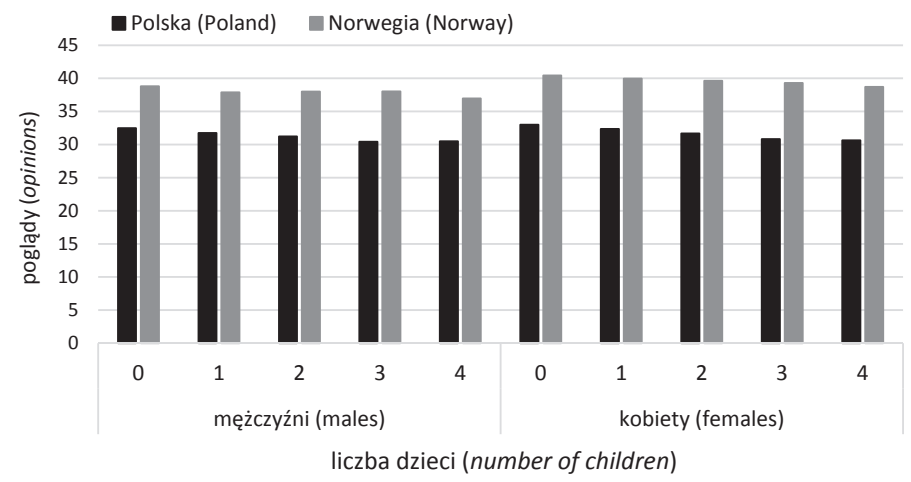

Źródło: obliczenia własne.

Source: own calculations.

Rysunek 9. Średnie poziomy zmiennej 'obciążenia obowiązkami’ według płci i liczby dzieci w Polsce i Norwegii

Figure 9. Mean values of the variable 'housework and childcare' by sex and number of children in Poland and Norway

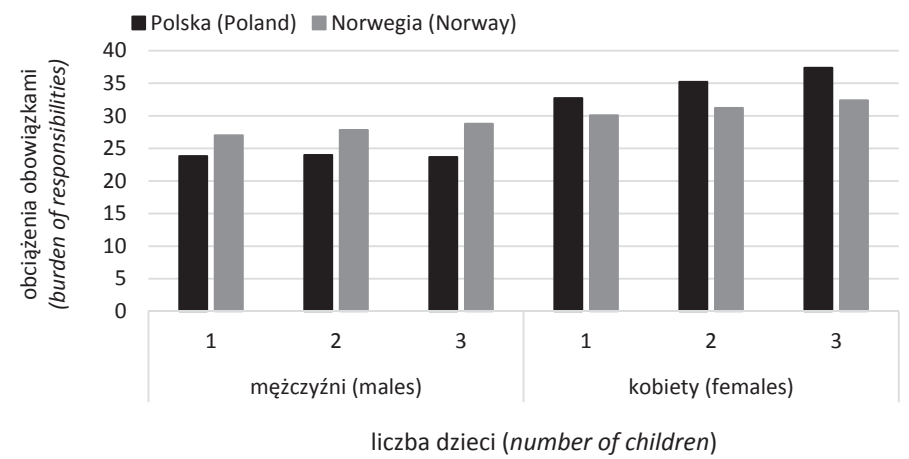

Źródło: obliczenia własne.

Source: own calculations.

Czynnikiem kształtującym poglądy na temat kulturowych ról płci jest również aktywność zawodowa. Jak wspominaliśmy wcześniej, rynek pracy w Norwegii charakteryzuje się stosunkowo dużym udziałem kobiet i mężczyzn pracujących na część etatu. W Polsce ta forma zatrudnienia jest znacznie mniej powszechna, zwłaszcza, w przypadku mężczyzn. Dane z badania GGS-1 pokazały, że ani aktywność zawodowa, ani nawet wymiar etatu pracy, nie różnicuje w statystycznie istotny sposób poglądów mężczyzn w Norwegii. Natomiast w Polsce mężczyźni zatrudnieni w niepełnym wymiarze godzin wyróżniali się w porównaniu do pozostałych najbardziej 
egalitarnymi poglądami. Z kolei istotnie bardziej tradycyjne poglądy miały kobiety bierne i bezrobotne w porównaniu do pracujących. W Norwegii wyróżniały się tylko kobiety pracujące na pełnym etacie, których poglądy były istotnie bardziej egalitarne (Rysunek 10).

Rysunek 10. Średnie poziomy zmiennej ‘poglądy’ według płci i aktywności zawodowej w Polsce i Norwegii

Figure 10. Mean values of the variable 'opinions' by sex and economic activity in Poland and Norway

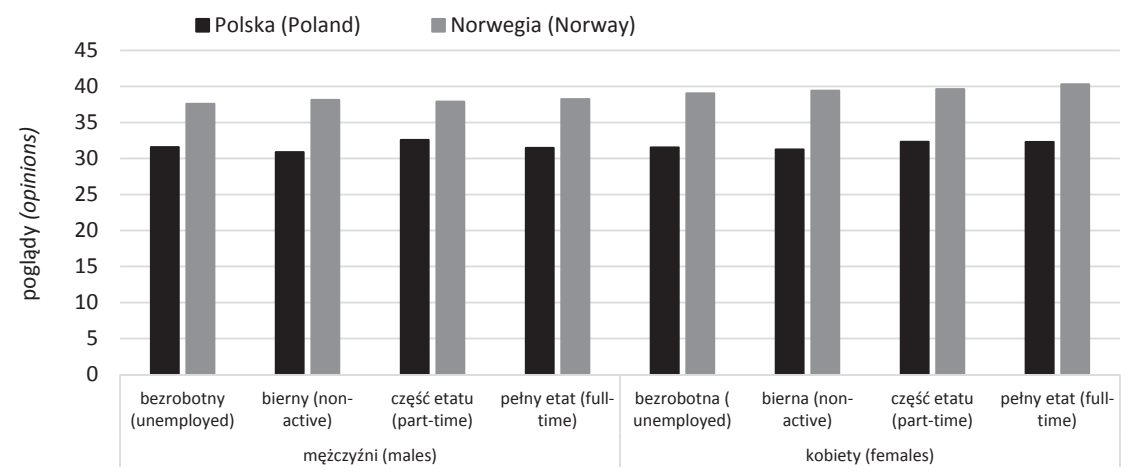

Źródło: obliczenia własne.

Source: own calculations.

Kobiety w Norwegii charakteryzują się dość niewielkim zróżnicowaniem w obciążeniu obowiązkami według statusu na rynku pracy. Niezależnie od zaangażowania w aktywność zawodową średni stopień obciążenia był bardzo zbliżony (aczkolwiek różnice były istotne statystycznie). W Polsce obciążenie obowiązkami rodzinnymi kobiet, niezależnie od statusu na rynku pracy, było wyższe niż w Norwegii i silniej zróżnicowane. Im więcej czasu kobiety poświęcały pracy zawodowej, tym w mniejszym stopniu były obciążone pracami domowymi i opiekuńczymi. Dla mężczyzn istotna różnica pomiędzy Polską i Norwegią ujawniła się tylko wśród mężczyzn pracujących na pełnym etacie, wśród których Norwegowie wykonywali więcej obowiązków niż Polacy. W pozostałych grupach statusu na rynku pracy ojców bezrobotnych, biernych zawodowo, a w Polsce również pracujących na część etatu, było zbyt mało w badaniu, aby ujawnione różnice w obciążeniu obowiązkami domowymi i opiekuńczymi okazały się statystycznie istotne (Rysunek 11).

Aby wskazać zależności pomiędzy obciążeniem obowiązkami a poglądami na temat kulturowych ról płci w obu krajach wykorzystano podział na trzy kategorie poglądów (tradycyjny, umiarkowany i nowoczesny) wyznaczony dla kobiet i mężczyzn według odchyleń standardowych uzyskanych z rozkładów dla respondentów z Polski. Obliczone średnie wartości wskaźników „obciążenia obowiązkami” dla osób o takich samych typach poglądów potwierdziły, że w Norwegii mężczyźni podejmowali się większej liczby obowiązków niż w Polsce, wśród kobiet było 
odwrotnie niezależnie od poglądów (Rysunek 12). W obu krajach jednak kierunek zmian obciążeń obowiązkami był taki sam. Najmniejsze obciążenia były wśród mężczyzn o poglądach tradycyjnych i wśród kobiet o poglądach nowoczesnych, a największe wśród mężczyzn o poglądach nowoczesnych i wśród kobiet tradycyjnie wypowiadających się o roli płci.

Istotne różnice pomiędzy krajami pojawiły się w rozkładach procentowych według kategorii poglądów i stopnia obciążenie. W tabelach 4 i 5 skonstruowanych według kategorii „poglądów” i „obciążeń obowiązkami” wyznaczonych dla Polski,

Rysunek 11. Średnie poziomy zmiennej 'obciążenia obowiązkami’ według płci i aktywności zawodowej w Polsce i Norwegii

Figure 11. Mean values of the variable 'housework and childcare' by sex and economic activity in Poland and Norway

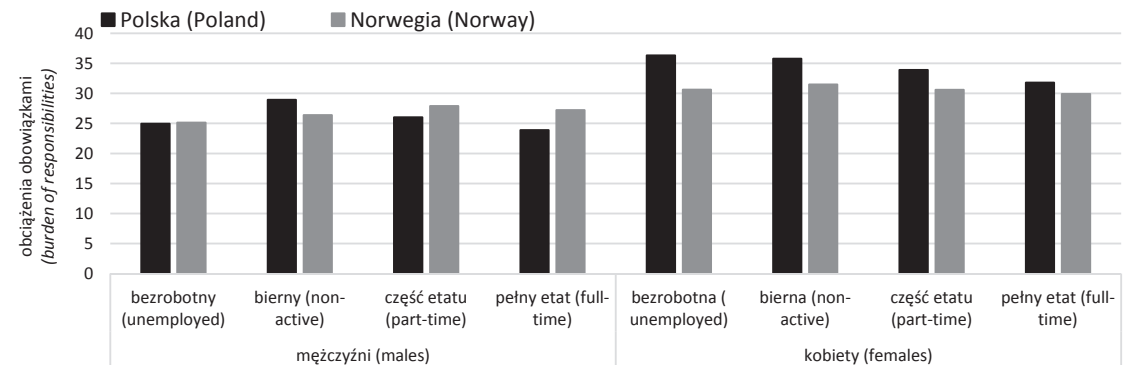

Źródło: obliczenia własne.

Source: own calculations.

Rysunek 12. Średnie poziomy zmiennej ‘obciążeń obowiązkami’ w Polsce i Norwegii według płci i kategorii obciążeń obowiązkami i poglądów w Polsce

Figure 12. Mean values of the variable 'housework and childcare' in Poland and Norway by sex and Polish categories of the variable 'opinions'

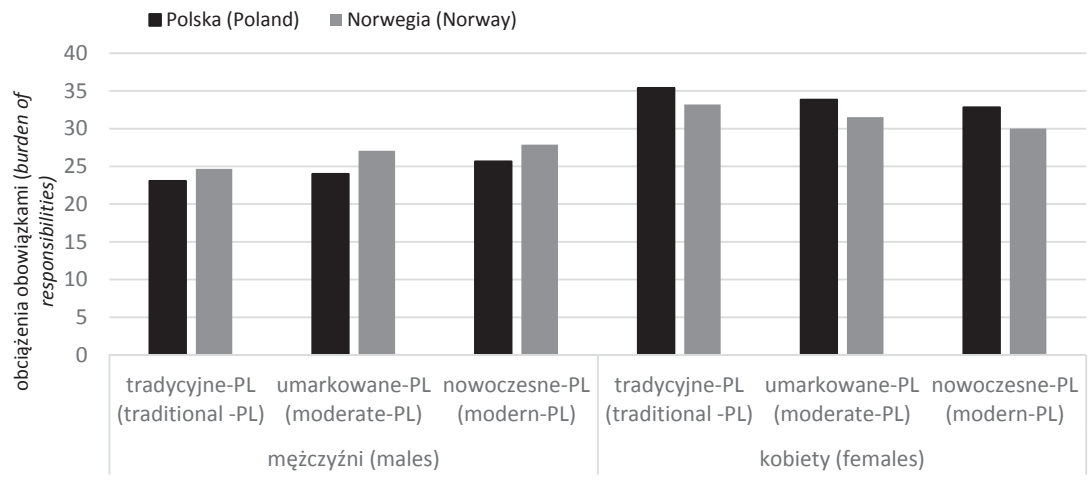

poglądy (opinions)

Źródło: obliczenia własne.

Source: own calculations. 
umieszczono procentowe udziały respondentów z obu krajów posiadających jedno lub dwoje dzieci. Okazało się, że wśród respondentek z Norwegii nie było kobiet o tradycyjnych „polskich” poglądach i mających małe i duże „polskie” obciążenie obowiązkami, a wśród mężczyzn tak samo i dodatkowo posiadających małe "polskie” obciążenie i „polskie” umiarkowane poglądy. Takie zestawienia nie pozwalają jednoznacznie wskazać, w którym kraju było więcej kobiet i mężczyzn odczuwających niekorzystnie nierównowagę pomiędzy poglądami i obciążeniami domowymi i opiekuńczymi, ale pokazują, w którym było względnie więcej osób o nowoczesnych czy umiarkowanych poglądach i posiadających małe lub umiarkowane obciążenie obowiązkami.

Największe różnice pomiędzy krajami ujawniły się wśród osób o nowoczesnych poglądach. W Norwegii było 19\%, mężczyzn deklarujących nowoczesne ,polskie” poglądy i równocześnie duże ,polskie” obciążenia, w Polsce - 3\%. Kobiety o nowoczesnych ,polskich” poglądach i małym ,polskim” obciążeniu w Norwegii stanowiły $20 \%$ wszystkich kobiet, w Polsce tylko $2 \%$. Według zastosowanego podziału w Polsce najwięcej było respondentów o umiarkowanych poglądach i średnim obciążeniu, a w Norwegii o nowoczesnych „polskich” poglądach i „polskim” średnim obciążeniu. Powyższe wyniki, ze względu na reprezentatywny charakter próby, pozwalają stwierdzić, że w Norwegii około $70 \%$ mężczyzn posiadało nowoczesne poglądy $\mathrm{i}$ według polskich kategorii wykonywali obowiązki rodzinne z zaangażowaniem średnim i dużym, zaś w Polsce - około 14\%. Natomiast kobiety o nowoczesnych poglądach i z małym lub średnim stopniem obciążenia obowiązkami (według polskich kategorii) stanowiły w Norwegii około $75 \%$ respondentek, w Polsce - zaledwie $11 \%$. Różnice te potwierdzają dystans pomiędzy krajami w procesie przemian kulturowych ról płci zarówno w odniesieniu do poglądów jak i obciążeń obowiązkami.

Uzupełnieniem powyższej analizy jest przedstawienie rozkładu średnich wartości miernika charakteryzującego satysfakcję z podziału obowiązków domowych i związanymi z opieką nad małymi dziećmi pomiędzy małżonkami/partnerami. Ze względu na różny rozkład procentowy respondentów z Polski i Norwegii można było porównać tylko niektóre kategorie poglądów i obciążeń. W obu krajach wśród kobiet średni stopień satysfakcji malał wraz ze wzrostem obciążenia obowiązkami domowymi i opiekuńczymi. Wyższy poziom satysfakcji wśród respondentek z Norwegii w porównaniu do Polski ujawniły kobiety o „,polskich” umiarkowanych poglądach z „polskim” małym obciążeniem, a mniejszą satysfakcję kobiety z „polskim” obciążeniem średnim i „polskimi” poglądami nowoczesnymi oraz umiarkowanymi. W pozostałych przypadkach różnice $\mathrm{w}$ poziomie satysfakcji wśród kobiet pomiędzy krajami były nieistotne. Wśród mężczyzn zarówno w Polsce jak i w Norwegii brak istotnych różnic wystąpił we wszystkich grupach niezależnie od poglądów i obciążeń (tabela 7 i 8). Dane z tabel ujawniły również wyższą satysfakcję mężczyzn w porównaniu do kobiet (w Polsce i Norwegii) we wszystkich kategoriach podziału, z wyjątkiem osób o ,polskich” małych obciążeniach. W tej kategorii różnice według płci były statystycznie nieistotne. 


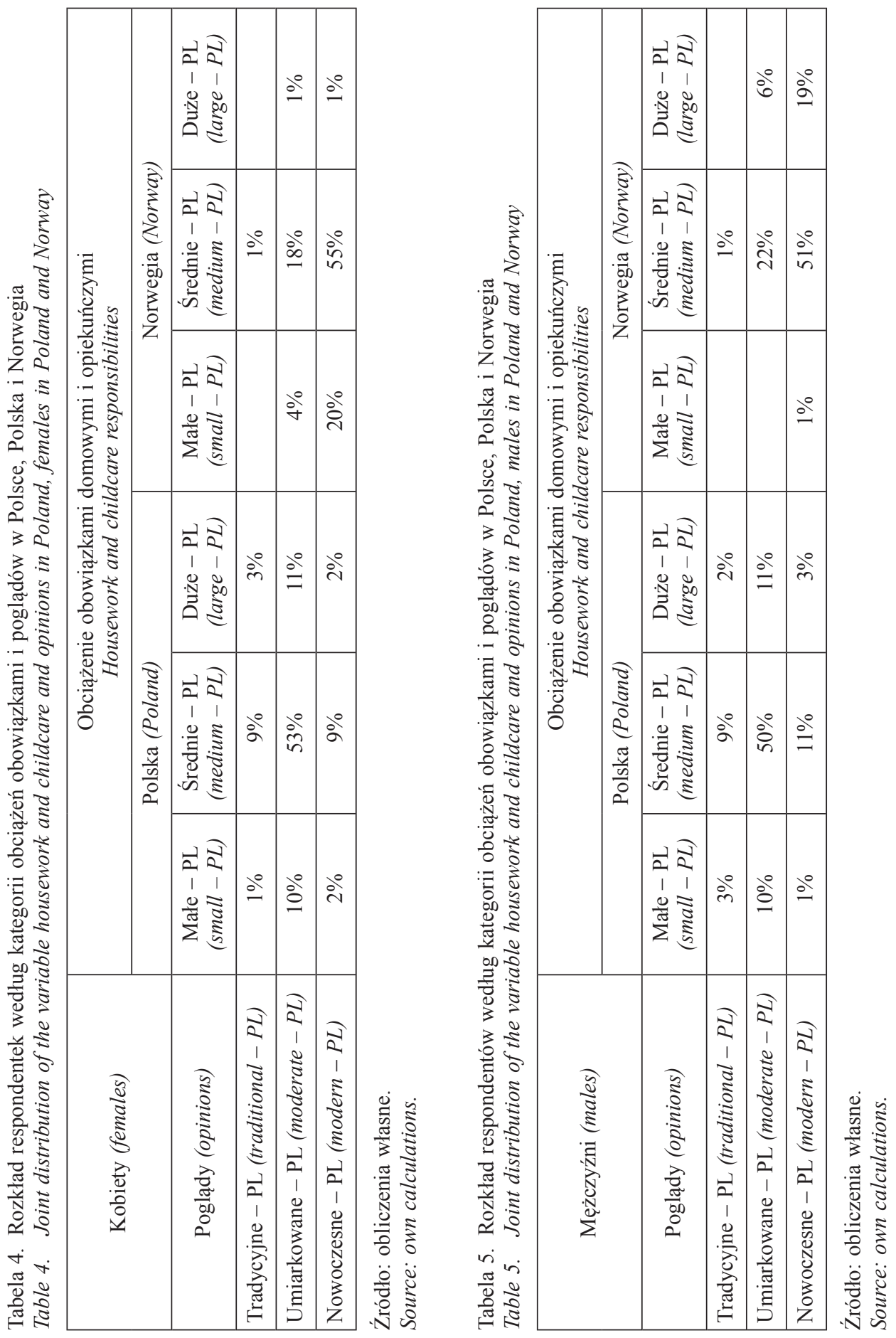




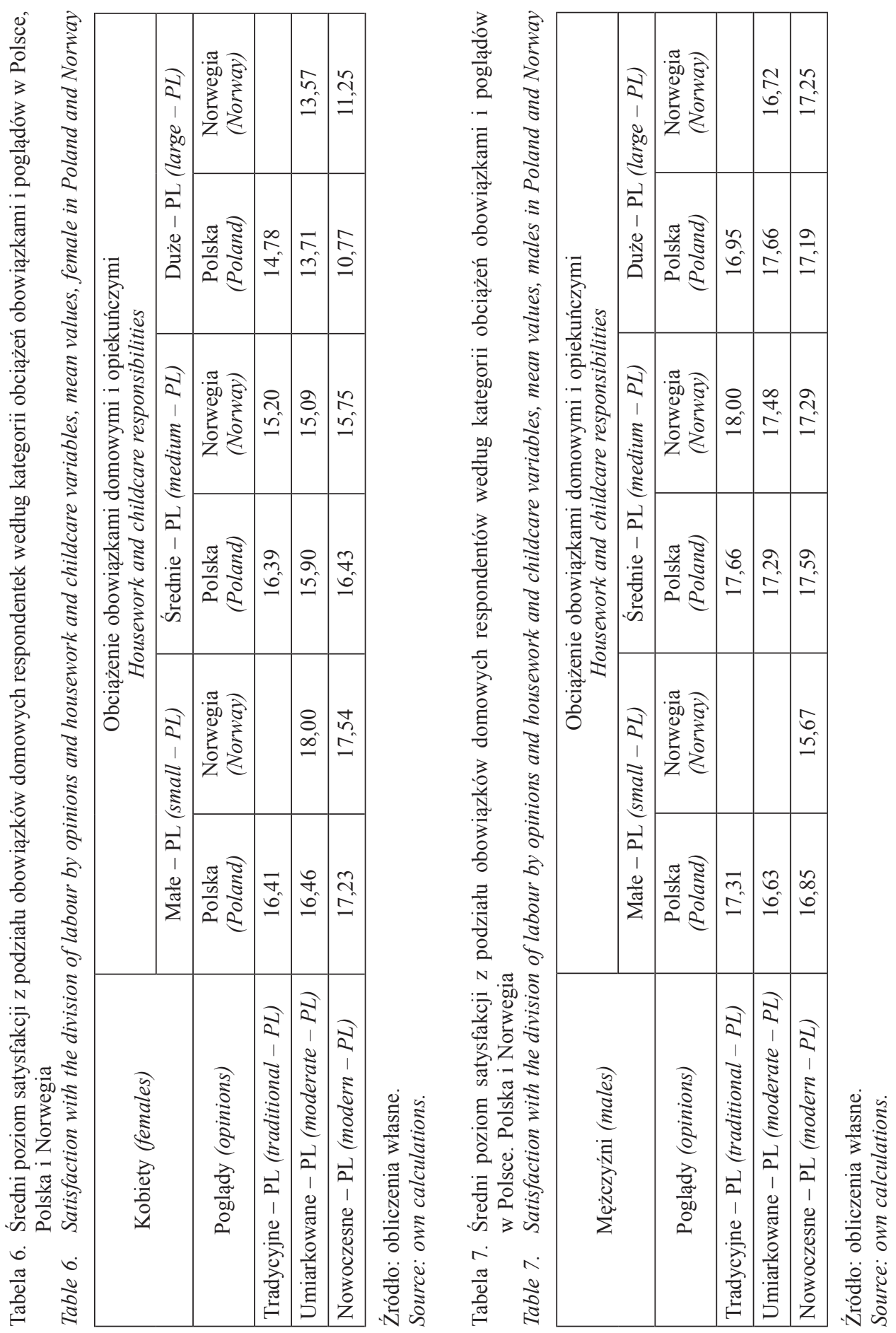


Wyniki dla kobiet wskazują jak ważna dla ich satysfakcji jest wielkość obciążenia obowiązkami domowymi i opiekuńczymi. Znaczenie poglądów ujawniło się wśród Polek z dużym obciążeniem obowiązkami. W tej grupie kobiety o nowoczesnych poglądach miały istotnie mniejszą satysfakcję od pozostałych. Respondentek z Norwegii w tej grupie obciążenia było zbyt mało, aby potwierdzić istotność poglądów, ale wielkości średnich poziomów satysfakcji mogą sugerować, że taki wniosek może być również poprawny dla Norwegii. Wśród mężczyzn brak istotnego zróżnicowania średnich poziomów satysfakcji w wyszczególnionych kategoriach pokazuje, że na poziom satysfakcji istotne znaczenie mogą mieć inne elementy życia rodzinnego, a nie tylko obciążenie obowiązkami i poglądy.

Znaczenie postaw deklarowanych i realizowanych na dzietność pokazują dwa rozkłady: średniej liczby dzieci według kategorii poglądów osób, które deklarowały, że zdecydowanie nie chcą mieć kiedykolwiek więcej dzieci i intencje urodzenia drugiego i trzeciego dziecka według poglądów i obciążenia obowiązkami (Rysunek 13 i 14). Generalnie osoby o poglądach tradycyjnych miały więcej dzieci w obu krajach, a te o nowoczesnych poglądach - mniej. Największe zróżnicowanie średniej liczby dzieci ujawniło się wśród kobiet w Polsce. Norweżki zarówno o poglądach tradycyjnych jak i umiarkowanych posiadały średnio taką samą liczbę dzieci. Porównanie to pokazało również, że w Norwegii w rodzinach mężczyzn o nowoczesnych poglądach średnia liczba dzieci nie była mniejsza niż Polaków o tradycyjnych poglądach, a Norweżki o poglądach umiarkowanych i nowoczesnych miały średnio więcej dzieci niż Polki. Tylko w przypadku poglądów tradycyjnych średnie wielkości rodzin kobiet w obu krajach nie różniły się istotnie (Rysunek 13). Wyższe średnie liczby dzieci w norweskich rodzinach niż w polskich niezależnie od poglądów (z wyjątkiem tradycyjnych kobiet) świadczą o znaczeniu innych cech

Rysunek 13. Średnie liczby dzieci w rodzinach, w których zdecydowanie zadeklarowano brak intencji posiadania dziecka (lub kolejnego) według płci respondentów i kategorii poglądów w Polsce i Norwegii

Figure 13. Average number of children in families who definitely declared no intention of having any children (or more) by sex and opinions variable in Poland and Norway

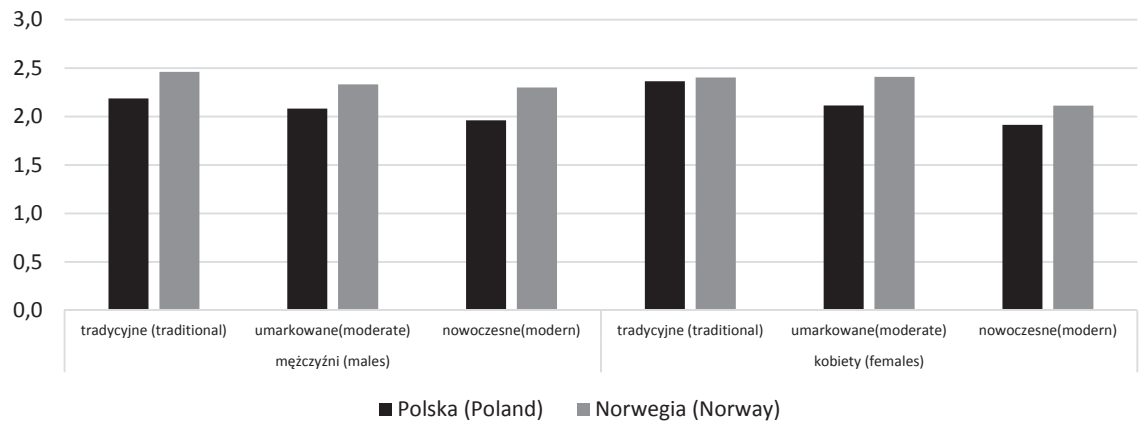

Źródło: obliczenia własne.

Source: own calculations. 
charakteryzujących warunki życia. Wyższy poziom dochodów gospodarstw domowych, lepsza instytucjonalna opieka nad dzieckiem i elastyczny rynek pracy oddziałują pozytywnie na decyzje o urodzeniu dziecka. Na podstawie dostępnych danych nie można było jednak ocenić znaczenia obciążeń obowiązkami rodzinnymi na podjęte wcześniej decyzje o liczbie posiadanych dzieci. Ocenę współzależności obciążeń obowiązkami uwzględniających poglądy przedstawiono poniżej dla intencji prokreacyjnych krótkoterminowych (planowane urodzenie dziecka w ciągu trzech lat).

Badanie Generations and Gender Survey pomimo dużej próby nie pozwala na analizy uwzgledniające jednocześnie kilka cech (np. wiek, kategorie postaw i intencji prokreacyjnych) ze względu na niewystarczające liczebności. Aby jednak pokazać znaczenie obciążeń obowiązkami rodzinnymi zagregowano intencje dotyczące urodzeń drugiej i trzeciej kolejności. Rysunek 14 przedstawia rozkład intencji kobiet i mężczyzn w Polsce i Norwegii jednocześnie według poglądów i obciążeń obowiązkami ${ }^{9}$. W obu krajach wśród kobiet o poglądach umiarkowanych i nowoczesnych częstość intencji zmniejszała się wraz ze zwiększaniem się obciążeń obowiązkami rodzinnymi. Dotyczyło to również Norweżek posiadających poglądy tradycyjne. Wyjątkiem okazały się Polki o takich poglądach, wśród których częstość intencji prokreacyjnych rosła wraz z obciążeniami obowiązkami domowymi. W przypadku mężczyzn kierunek zależności nie był tak jednoznaczny. Brakuje wyraźnej zależności wśród Polaków we wszystkich kategoriach poglądów i wśród Norwegów

Rysunek 14. Częstość intencji prokreacyjnych według płci, kategorii poglądów i obciążeń obowiązkami w Polsce i Norwegii

Figure 14. The frequency of reproductive intentions by sex, variable opinions and housework and childcare variable in Poland and Norway

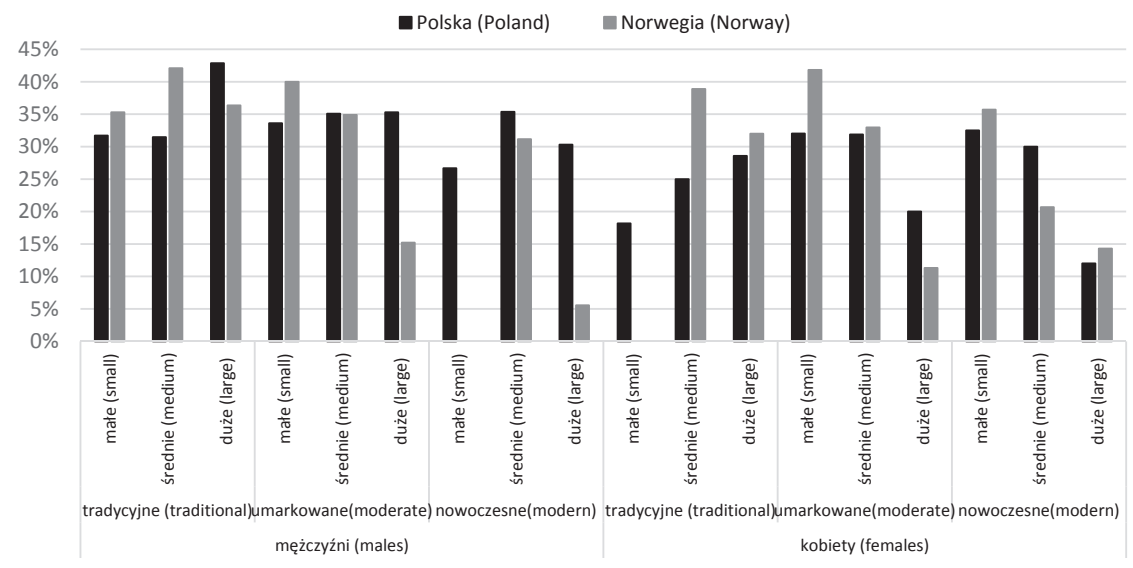

Źródło: obliczenia własne.

Source: own calculations.

9 W niektórych grupach kategorii wskaźników „poglądy” i „obciążenia obowiązkami” częstości intencji prokreacyjnych zostały pominięte ze względu na bardzo małe liczebności respondentów. 
o tradycyjnych poglądach. Większe obciążenie obowiązkami ujawniło ujemną współzależność z intencjami prokreacyjnymi wśród mężczyzn w Norwegii o poglądach umiarkowanych i nowoczesnych. Ten ostatni rezultat wśród mężczyzn i wyniki dla kobiet wskazują na znaczenie nie tylko podziału obowiązków pomiędzy partnerami/współmałżonkami, ale również na rolę osób trzecich lub instytucji pomagających w wypełnianiu obowiązków domowych i opiekuńczych.

\section{PODSUMOWANIE}

Powyższe zestawienia poglądów, obciążeń obowiązkami i satysfakcji z podziału obowiązków domowych i związanymi z opieką nad małymi dziećmi pomiędzy małżonkami/partnerami w obu krajach pokazały dość zróżnicowany obraz przemian kulturowych ról płci. Analiza potwierdziła, że Norwegia jest krajem o wyraźnie wyższym poziomie egalitaryzmu niż Polska. Porównanie dotyczyło stosunkowo młodej grupy wieku 20-44 lata, z których najmłodsi Polacy urodzili się już po zmianach ustrojowych, a najstarsi prawie całe dorosłe życie spędzili w nowej rzeczywistości. Jednak zestawiając ich poglądy z Norwegami w tym samym wieku widać, że postawy wobec kulturowych ról płci różnią się istotnie. Interesująca jest dość duża zgodność w Polsce rozkładów dla kobiet i mężczyzn i skupienie wartości wskaźników w środku skali.

Wskaźniki obciążeń obowiązkami domowymi i opiekuńczymi w porównaniu do wskaźników poglądów były bardziej zróżnicowane według krajów i płci. Przede wszystkim w Polsce ujawniły się duże różnice pomiędzy obciążeniami wśród kobiet i mężczyzn. Średnie obciążenie dla mężczyzn było aż o dwa odchylenia standardowe (wyznaczone dla wszystkich) niższe niż dla kobiet, gdy w Norwegii różnica ta wynosiła niecałe jedno odchylenie standardowe. W wartościach bezwzględnych różnica dla Polski wydaje się jeszcze większa.

Wyniki analizy poglądów na role płci i obciążeń obowiązkami rodzinnymi pokazały, że mężczyźni o bardziej egalitarnych poglądach przejmują więcej obowiązków, a kobiety o tych samych poglądach obciążone są w mniejszym stopniu w porównaniu do osób z poglądami tradycyjnymi. Jednak stopień obciążenia obowiązkami wśród tych mężczyzn był znacznie mniejszy niż wśród kobiet o takich samych nowoczesnych poglądach, nawet w Norwegii.

Rozkłady obciążeń według poglądów pokazały również, że w Norwegii jest znacznie więcej kobiet o nowoczesnych poglądach, które jednocześnie mają średnie i małe obciążenie i więcej mężczyzn o takich samych poglądach, ale dużych obciążeniach. Natomiast w rozkładzie satysfakcji z podziału obowiązków między współmałżonkami/partnerami nie ujawniła się w obu krajach żadna najbardziej lub najmniej usatysfakcjonowana grupa mężczyzn, nawet najwyżej obciążonych. Jedynie wśród kobiet najwyższą satysfakcję ujawniły Norweżki o poglądach umiarkowanych i małym obciążeniu. Natomiast Polki zadeklarowały większą satysfakcję niż 
Norweżki wśród kobiet o nowoczesnych i umiarkowanych poglądach oraz średnim obciążeniu obowiązkami domowymi.

Istotnym rezultatem analizy było ujawnienie słabego związku aktywności zawodowej i postaw wobec kulturowych ról płci (deklaratywnych i realizowanych) w Norwegii. Takie słabe znaczenie stopnia zaangażowania na rynku pracy może wynikać z dużego od lat rozpowszechnienia zatrudnienia na część etatu wśród kobiet i także wśród mężczyzn. Poglądy nie mają już wpływu na to czy pracować, a jedynie na formę zatrudnienia (na pełny etat lub na część etatu). W Polsce status na rynku pracy istotnie różnicował przede wszystkim obciążenie kobiet obowiązkami domowymi i opiekuńczymi. Im mniej czasu kobieta poświęcała pracy zawodowej, tym większe miała obciążenie $\mathrm{w}$ domu.

Opisany w analizie dystans $\mathrm{w}$ postawach deklaratywnych i realizowanych w rodzinie pomiędzy Polską i Norwegią wskazuje, że w Polsce występuje większy dystans pomiędzy kobietami i mężczyznami w obciążeniu obowiązkami domowymi i opiekuńczymi względem małych dzieci. Różnicę tę tylko w części można wyjaśnić bardziej tradycyjnymi poglądami Polaków. Potwierdzeniem tego jest najwyższa satysfakcja kobiet o nowoczesnych poglądach i małym oraz średnim obciążeniu obowiązkami oraz najniższa satysfakcja wśród kobiet o największym obciążeniu. Ponadto w Polsce różnica pomiędzy poglądami kobiet biernych zawodowo i pracujących w pełnym wymiarze godzin była istotna, ale bardzo zbliżona do różnicy w Norwegii.

Porównanie postaw deklaratywnych i realizowanych w Polsce i Norwegii na podstawie danych z pierwszej tury badania Generations and Gender Survey pokazało nie tylko to, że Polska jest krajem bardziej tradycyjnym, i że Polki są bardziej obciążone obowiązkami niż Norweżki, ale przede wszystkim, że podobne są kierunki zależności pomiędzy poglądami i obciążeniami obowiązkami a liczbą dzieci w rodzinie i częstością intencji prokreacyjnych. Analiza ujawniła, że w obu krajach osoby o bardziej egalitarnych poglądach, które deklarowały zakończenie prokreacji, miały mniejszą średnią liczbę dzieci niż osoby o tradycyjnych poglądach oraz niezależnie od poglądów kobiet im w większym stopniu były obciążone obowiązkami rodzinnymi tym rzadziej wyrażały intencje urodzenia drugiego i trzeciego dziecka. Wyjątkiem były jedynie Polki o tradycyjnych poglądach, dla których większe obciążenie obowiązkami nie zmniejszało częstości tych intencji prokreacyjnych. W świetle powyższych rezultatów korzystniejsze rozwiązania na rynku pracy i zachowania $\mathrm{w}$ rodzinie pomagające $\mathrm{w}$ łączeniu pracy zawodowej i obowiązków domowych w Norwegii mogą być wyjaśnieniem większej dzietności w tym kraju. Zwłaszcza, że dane z Norwegii pokazały, że rozpowszechnianie nowoczesnych poglądów nie musi oznaczać mniejszej liczby dzieci w rodzinie. Wprawdzie osoby o poglądach tradycyjnych miały więcej dzieci w obu krajach, a te o nowoczesnych poglądach mniej, ale w rodzinach Norwegów o nowoczesnych poglądach średnia liczba dzieci nie była mniejsza niż w rodzinach Polaków o tradycyjnych poglądach.

Zmianom kulturowych ról płci w Europie w kierunku coraz większego równouprawnienia towarzyszyło i dalej towarzyszy w wielu krajach rozpowszechnianie się 
ekonomicznego modelu rodziny, w którym zarówno mężczyzna jak i kobieta pracują zawodowo (dual earner family). Jednak tylko w sferze publicznej prawa i obowiązki kobiet i mężczyzn się wyrównały (McDonald 2000a). Zmiany postaw wobec ról pełnionych w rodzinie przebiegają znacznie wolniej (Blossfeld i Drobnic 2001), co oznacza, że tradycyjny model przypisujący kobiecie wypełnianie obowiązków domowych i opiekuńczych w dalszym ciągu postrzegany jest jeszcze w wielu rodzinach jako oczywisty. W konsekwencji obserwujemy powszechne występowanie modelu z podwójnym obciążeniem kobiet (dual earner - double burden of women) (Matysiak 2006, Kotowska 2005, 2009). Jednak zakres tego obciążenia oraz stopniowe włączanie się mężczyzn w obowiązki domowe jest zróżnicowany w krajach europejskich, co również zostało potwierdzone w tej analizie. Kraje skandynawskie są najbliżej zrównania płci w sferze rodzinnej. Przykład norweski pokazuje, że proces upowszechnienia modelu, w którym zarówno mężczyzna jak i kobieta pracują zawodowo i wspólnie wypełniają obowiązki rodzinne w sytuacji rozpowszechniania się nowoczesnych poglądów i oczekiwania od kobiet współodpowiedzialności za materialny byt rodziny, a od mężczyzn - dzielenia z kobietami zobowiązań rodzinnych sprzyja większej liczbie dzieci w rodzinie. Ukazanie dystansu między Polską a Norwegią w przedstawionej analizie porównawczej ilustruje znaczenie przemian kulturowych w Polsce dla przyszłych zmian dzietności. Bez większego zaawansowania tych przemian nie można oczekiwać trwałego wzrostu dzietności.

\section{LITERATURA}

Ahn, N., Mira P., 2002, A note on the changing relationship between fertility and female employment rates in developed countries. ,Journal of Population Economics”, 15, 667-682.

Arpino B., Esping-Andersen G., Pessin L., 2015, How Do Changes in Gender Role Attitudes Towards Female Employment Influence Fertility? A Macro-Level Analysis. „European Sociological Review”, 1-13.

Blossfeld H-P., Drobnič S., (red.) 2001, Careers of Couples in Contemporary Societies: From Male Breadwinner to Dual-Earner Families. Oxford: Oxford University Press.

D'Addio, A. C., d'Ercole M. M., 2005, Trends and determinants of fertility rates in OECD countries: The role of policies, „OECD Social, Employment and Migration Working Paper”, 27. Paris, OECD.

Del Boca D., Aaberge R., Colombino U., Ermisch J., Francesconi M., Pasqua S., Strom S., 2003, Labour market participation of women and fertility: the effect of social policies. In FRDB Child Conference. Alghero., ttp://www.frdb.org/upload/file/copy_0_paper_delboca.pdf

Engelhardt, H., Prskawetz A., 2004, On the changing correlation between fertility and female employment over space and time. „European Journal of Population”, 20, 35-62.

Esping-Andersen G., 2009, The Incomplete Revolution: Adapting to Women's New Roles. Malden, MA: Polity Press.

Esping-Andersen G, Billari F., 2015, Re-theorizing Family Demographics, „Population and Development Review" 41 (1), 1-31.

Frejka T., 2008, Determinants of family formation and childbearing during the societal transition in central and Eastern Europe, [w:] T. Frejka, T. Sobotka, J.M. Hoem, L. Toulemon (red.) Childbearing Trends and Policies in Europe, „Demographic Research”, nr 19; Article 22: 139-170.

Gimenez-Nadal J.I., Molina J., Sevilla-Sanz A., 2012, Social norms, partnerships and children, „Review of Economics of the Household", vol. 10, nr 2, 215-36. 
Goldscheider F., Bernhardt E., Lappegård T., 2014, The second half of the gender revolution in Sweden: Will it strengthen the family? Domestic Gender Equality and Modern Family Patterns Working Paper Series, EQUAL WP 07 March 2014.

Goldscheider F., Bernhardt E., Lappegård T., 2015, The Gender Revolution: A Framework for Understanding Changing Family and Demographic Behavior, Article first published online: 16 Jun 2015, DOI: 10.1111/j.1728-4457.2015.00045.x, „Population and Development Review”, vol. 41, Issue 2, 207-239.

Goldscheider F., Oláh L., Puur A., 2010, Reconciling studies of men's gender attitudes and fertility; Response to Westoff and Higgins, „Demographic Research”, nr 22, 8, 189-198. http://www.demographicresearch.org/Volumes/Vol22/8/

Hawken A., Munck G.L., 2012, Cross-National Indices with Gender-Differentiated Data: What Do They Measure? How Valid Are They? „Social Indicators Research”, 111 (3).

Hobson B., 1990. No Exit, No Voice: Women's Economic Dependency and the Welfare State. „Acta Sociologica", 33, 235-50.

Inglehart R., 1977, The Silent Revolution: Changing Values and Political Systems among Western Publics, Princeton University Press, Princeton.

Kałwa D., Klich-Kluczewska B., 2012, Od „Pani domu” do „Panny Nikt”? Krótka historia niepłatnej pracy domowej kobiet $w$ Polsce, w: Nieodpłatna praca kobiet - różowa strefa gospodarki, Fundacja Feminoteka, Warszawa, 20-25.

Kotowska I.E., 1999, Drugie przejście demograficzne i jego uwarunkowania, [w:] I.E. Kotowska (red.), Przemiany demograficzne w Polsce w latach 90. w świetle drugiego przejścia demograficznego, Warszawa: Oficyna Wydawnicza SGH.

Kotowska I.E., 2005, Work and parenthood: main findings of comparative data analysis and some policy implications, „Studia Demograficzne”, nr 148, 2, 54-82.

Kotowska I.E., 2009, Zmiany modelu rodziny a zmiany aktywności zawodowej kobiet w Europie, [w:] I.E. Kotowska (red.), Strukturalne i kulturowe uwarunkowania aktywności zawodowej kobiet w Polsce, Wydawnictwo Naukowe SCHOLAR.

Kögel T., 2004, Did the association between fertility and female employment within OECD countries really change its sign? „Journal of Population Economics”, 17(1), 45-65.

Lappegård T., Neyer G., Vignoli D., 2015, Three dimensions of the relationship between gender role attitudes and fertility intentions, Stockholm University, Working Paper, 4.

Lesthaeghe R. 2010, The Unfolding Story of the Second Demographic Transition, Research Report 10-696, Population Studies Center.

Lesthaeghe R., Kaa D.J. van de, 1986, Twee demografische transities, [w:] D.J. van de Kaa, R. Lesthaeghe (red.), Bevõlking: groei en krimp, Deventer: van Loghem Slaterus.

Matysiak A., 2006, Sharing Professional and household duties within the Polish couples - preferences and actual choices, „Studia Demograficzne”, nr 1, 147, 122-153.

Matysiak A., 2011, Interdependencies between Fertility and Women's Labour Supply (Dortrecht, Heidelberg, London, New York: Springer, European Studies of Population 17).

Matysiak A., Węziak-Białowolską D., 2013, Country-Specific Conditions for Work and Family Reconciliation: An Attempt at Quantification, „Zeszyty naukowe”, nr 31, Instytut Statystyki i Demografii SGH.

McDonald P., 2000a, Gender equity in theories of fertility, „Population and Development Review”, nr 26, 3, 427-439.

McDonald P., 2000b, Gender equity, social institutions and the future of fertility, „Journal of Population Research", nr. 17, 1, 1-12.

Orloff A.S., 1993, Gender and the Social Rights of Citizenship: The Comparative Analysis of Gender Relations and Welfare States. „American Sociological Review” 58(3): 303-328.

Puur A., Oláh L.S., Tazi-Preve M.I., Dorbritz J., 2008, Men's childbearing desires and views of the male role in Europe at the dawn of the 21st century, „Demographic Research”, vol. 19, nr 56, 1883-912. 
The Role of Men in Gender Equality - European strategies and insights, 2012, European Commission, DG Justice - Unit D2 Gender equality, December 2012.

Sevilla-Sanz A., 2010, Household division of labor and cross-country differences in household formation rates, „Journal of Population Economics”, vol. 23, nr 1, 225-49.

Siemieńska R., 1996, Kobiety: nowe wyzwania. Starcie przeszłości z teraźniejszościa, Instytut Socjologii UW, Warszawa.

Siemieńska R., 2011, Kontrakt ptci. Między sfera prywatna i publiczną, w: Gender w społeczeństwie polskim, Slany K., Struzik J., Wojnickiej K., NOMOS, Kraków.

Smith A.J., 2004, Who Cares? Fathers and the Time They Spend Looking After Children, Sociology Working Papers 2004-05, Department of Sociology University of Oxford, www.sociology.ox.ac. uk/swp.html.

\title{
GENDER ROLES AND FERTILITY IN POLAND AND NORWAY
}

\begin{abstract}
Changing gender roles are increasingly considered as a driving factor of both fertility decline in European countries and its recovery in some of these countries. The fertility decline is attributed to the first stage of the gender revolution when increasing women's labour force participation is accompanied by some progress in gender equality in the public sphere while in the family life a gender asymmetry remains. During the second stage of the gender revolution the progress towards new roles of men and women in the private sphere takes place - they both are considered as economic providers and careers and share work and family responsibilities (e.g. McDonald 2000b, Goldscheider, Bernhardt, Lappegård 2015, Esping-Andersen, Billari 2015).

The article compares on-going changes in gender roles in Poland and Norway, two countries which are at different stages of this process, and their interplay with fertility (mean number of children and intensions about the second and third child). Attitudes towards gender equality are studied by taking into account views on this issue on one side and sharing care and housework on the other. Data come from the first round of the Generations and Gender Survey. The study has been performed for respondents aged 20-44, living together with a partner and children under 14 years of age.

The descriptive analyses showed that Poles are not only less advanced in gender role changes in two gender dimensions studied: their views on gender roles are more traditional than Norwegian ones, women's share in family duties is higher contrary to men who contribute less to family responsibilities than women and men in Norway. There is also a higher variation of views and practices among Poles.
\end{abstract}


In Poland and Norway, egalitarian men participate more in family duties than those who declare traditional views, while egalitarian women are less burdened by home work and care. However, in Norway there is remarkably more egalitarian women with low and medium share of domestic duties in parallel to more numerous egalitarian men who take a great share of family responsibilities.

More egalitarian respondents have fewer children than the traditional ones in both countries. However, the mean number of children among this group of respondents in Norway is higher than in Poland. Moreover, women in both countries are less inclined to declare intensions to have a second or third child when they participate more in care and domestic duties. This relationship has been found for men in Norway as well.

Keywords: gender equality, gender attitudes, housework and childcare responsibilities, fertility 